Prosiding Seminar Nasional Pembangunan dan Pendidikan Vokasi Pertanian

Politeknik Pembangunan Pertanian Manokwari, 31 Juli 2021

e ISSN : 2774-1982

DOI : https://doi.org/10.47687/snppvp.v2i1.171

\title{
Seroprevalensi Brucellosis pada Sapi Potong di Papua Barat
}

\author{
Sulaxono Hadi ${ }^{*}$, Ratna Loventa Sulaxono ${ }^{1}$ \\ ${ }^{1}$ Balai Besar Veteriner Maros \\ *Corresponding author: idahonoxalus@gmail.com
}

\begin{abstract}
Abstrak
Brucellosis merupakan penyakit bakterial yang disebabkan oleh Brucella abortus, yang mengakibatkan kerugian ekonomi akibat terjadinya keguguran pada sapi betina yang bunting pada triwulan ketiga kebuntingan. Surveilans brucellosis dalam mendukung pengembangan peternakan sapi di Propinsi Papua Barat telah dilakukan oleh Balai Besar Veteriner Maros. Tujuan pelaksanaan surveilans ini adalah untuk mengetahui seroprevalensi brucellosis pada sapi potong di Papua Barat. Surveilans dilakukan di 4 kabupaten/kota, 14 kecamatan dan 33 desa. Sebanyak 684 sampel serum sapi telah diambil guna pengujian terhadap brucellosis. Sampling dilakukan pada lokasi kabupaten, kecamatan dan desa terpilih yang padat ternak. Metode pengujian dilakukan secara seri, dengan melakukan screening test menggunakan Rose Bengal Test, yang bila hasilnya positif diuji lebih lanjut dengan Complement Fixation Test. Hasil pengujian menunjukkan adanya reaktor brucellosis pada 5 ekor dari 684 ekor sapi yang diambil dan diuji serumnya. Seroprevalensi brucellosis pada sapi sebesar 0,73\% di desa Remu Utara, kecamatan Sorong, kota Sorong sebanyak 1 ekor serta di desa KaliMerah, kecamatan Masni, kabupaten Manokwari. Untuk mencegah penularan dan penyebaran brucellosis pada sapi maka sapi reaktor brucellosis segera dipotong dengan pengawasan dari petugas.
\end{abstract}

Kata kunci: Brucellosis, Reaktor brucellosis, Seroprevalensi

\section{Abstract}

Brucellosis is a bacterial disease caused by Brucella abortus, which causes economic loss due to miscarriage in pregnant cows in the third quarter of pregnancy. Brucellosis surveillance in support of the development of cattle farms in The Province of West Papua has been conducted by the Maros Veterinary Center. Brucellosis surveillance in support of the development of cattle farms in The Province of West Papua has been conducted by the Maros Veterinary Center. The purpose of this surveillance is to determine the seroprevalence of brucellosis in beef cattle in West Papua. Surveillance was conducted in 4 districts/ cities, 14 subdistricts and 33 villages. A total of 684 samples of cow serum have been taken for testing against brucellosis. Sampling is conducted at selected districts, subdistricts and villages that are densely populated with livestock. The testing method is done in series, by conducting a screening test using the Rose Bengal Test, which if the result is positive is further tested with the Complement Fixation Test. The test results showed the presence of brucellosis reactors on 5 heads of 684 cows taken and tested serum. Seroprevalence of brucellosis in cows by $0.73 \%$ in North Remu Village, Sorong Subistrict, Sorong City as much as 1 head as well as in Kalimerah Village, Masni Subdistrict, District of Manokwari. To prevent transmission and spread brucellosis in cows, brucellosis reactor cows are immediately cut with supervision from officers.

Keywords: Brucellosis, reactor brucellosis, seroprevalence 
Prosiding Seminar Nasional Pembangunan dan Pendidikan Vokasi Pertanian

Politeknik Pembangunan Pertanian Manokwari, 31 Juli 2021

e ISSN : 2774-1982

DOI : https://doi.org/10.47687/snppvp.v2i1.171

\section{PENDAHULUAN}

Provinsi Papua Barat memiliki potensi untuk pengembangan ternak sapi di wilayah Indonesia bagian Timur karena sumberdaya alamnya yang mendukung dalam penyediaan pakan ternak. Beberapa jenis ternak telah berkembang di propinsi ini diantaranya babi, ayam ras dan ayam buras serta sapi potong. Provinsi Papua Barat masih mendatangkan sapi dari pulau atau provinsi lainnya. Pada tahun 2019, sapi potong yang masuk provinsi ini sebanyak 1.610 ekor untuk keperluan pengembangan dan juga dipotong. Jumlah populasi sapi potong pada tahun 2019 sebanyak 51.738 ekor, yang meningkat dibanding tahun 2018 yang berjumlah 50.991 ekor (Nasrullah et al., 2019).

Dalam usaha pengembangan ternak sapi, selain pakan, masalah kesehatan yang terkait dengan penyakit dapat menjadi faktor penghambat yang merugikan. Salah satu penyakit menular yang bersifat zoonosis dan menyebabkan aborsi atau keguguran pada sapi betina yang bunting adalah brucellosis, yang disebabkan oleh Brucella abortus.

Brucellosis pada sapi merupakan salah satu penyakit yang sangat penting di dunia dan di Indonesia menjadi salah satu penyakit menular yang mendapat prioritas dalam pemberantasannya disamping 4 penyakit lainnya, rabies, avian influenza, anthrax, serta hog cholera. Brucellosis yang disebabkan oleh bakteri gram negatif berbentuk kokoid ini harus menjadi perhatian serius karena menyebabkan kerugian ekonomi berupa aborsi, kelemahan pada anak sapi yang terlahirkan sebagai akibat dari plasentitis, interstitial mastitis, fibrinous pleuritis, interstitial pneumonia pada foetus atau pada pedet yang baru lahir (Alcina et al., 2010). Brucellosis merupakan penyakit zoonotik, yang menyebabakan kegagalan reproduksi pada sapi bisa menular ke manusia, menyebabkan undulant fever pada manusia (Zamri-Saat et al., 2016).

Kegiatan surveilans brucellosis telah dilakukan oleh Balai Besar Veteriner bekerja sama dengan Dinas yang menangani pembangunan peternakan di provinsi dan kabupaten/kota di Provinsi Papua Barat pada tahun 2018 dengan maksud mengetahui seroprevalensi brucellosis dan menemukan sapi reaktor brucellosis, agar bisa dipotong dengan pengawasan dari petugas. Pemotongan sapi reaktor brucellosis adalah penting sebagai upaya mencegah penularan dan penyebaran ke sapi lainnya. Beberapa provinsi, pulau di Indonesia telah dinyatakan dengan keputusan Menteri Pertanian sebagai zona bebas dari penyakit brucellosis. Surveilans brucellosis di Papua Barat adalah salah satu upaya mendukung eradikasi brucellosis pada sapi di Papua Barat. 
Prosiding Seminar Nasional Pembangunan dan Pendidikan Vokasi Pertanian

Politeknik Pembangunan Pertanian Manokwari, 31 Juli 2021

e ISSN : 2774-1982

DOI : https://doi.org/10.47687/snppvp.v2i1.171

\section{METODE}

Sampling prevalensi didasarkan pada asumsi proporsi brucellosis $10 \%$, presisi sampling 5\%, tingkat konfidensi yang digunakan 95\%, dengan populasi sapi tahun 2018 sebesar 50.991 ekor. Jumlah sampel dihitung menggunakan pirantin Epitools, sample size for apparent or seroprevalence, maka jumlah sampel minimal yang diperlukan untuk populasi adalah 139 sampel. Sampel berupa serum sapi potong sebanyak 684 sampel diambil dari kabupaten/kota, kecamatan dan desa padat populasi sapi potongnya dari 4 kabupaten/kota, 14 kecamatan dan 33 desa/kelurahan.

Pengujian serum sapi dilakukan di Laboratorium Serologi Balai Besar Veteriner Maros menggunakan 2 metode yang dilakukan secara seri. Pengujian pertama yang merupakan screening test dilakukan menggunakan uji aglutinasi Rose Bengal Test (RBT) memnggunakan antigen produksi Pusat Veterinaria Farma Surabaya. Bila serum menunjukkan hasil positif RBT yang ditandai dengan terjadinya aglutinasi pada papan uji, maka dilanjutkan dengan uji konfirmatif menggunakan Complement Fixation Test (CFT) dengan komplemen buatan sendiri.

\section{HASIL DAN PEMBAHASAN}

Pengujian seri dengan CFT dimaksudkan untuk menekan false positif, uji RBT spesifitasnya rendah 39,58\%, walau sensitivitasnya 79,12\%, uji RBT juga bereaksi silang dengan infeksi bakterial lain (Zakaria, 2018). Gold standard uji brucellosis adalah kultur dan isolasi, atau identifikasi menggunakan uji imunihistokimia. Menggunakan uji kultur dan isolasi dari darah atau sumsum tulang memerlukan waktu yang lama, 7-4 hari hingga 40 hari (Geresu et al., 2016).

Dari sejumlah 684 serum sapi potong yang diuji seri dengan RBT dan CFT, ditemukan 5 ekor sapi reaktor brucellosis, positif uji RBT serta uji CFT-nya. Dari hasil ini diketahui besaran seroprevalensi brucellosis di Papua Barat adalah 0,73\%. Nilai yang kecil, kurang dari 2\%, yang menunjang untuk pemberantasan brucellosis di Papua Barat. 
Prosiding Seminar Nasional Pembangunan dan Pendidikan Vokasi Pertanian

Politeknik Pembangunan Pertanian Manokwari, 31 Juli 2021

e ISSN : 2774-1982

DOI : https://doi.org/10.47687/snppvp.v2i1.171

Tabel 1. Hasil pengujian brucellois per lokasi di Papua Barat tahun 2018

\begin{tabular}{|c|c|c|c|c|}
\hline $\begin{array}{c}\text { Nama } \\
\text { Kabupaten/Kota }\end{array}$ & $\begin{array}{c}\text { Nama } \\
\text { Kecamatan }\end{array}$ & $\begin{array}{c}\text { Jumlah } \\
\text { desa sampling }\end{array}$ & $\begin{array}{c}\text { Jumlah } \\
\text { sampel } \\
\text { serum }\end{array}$ & $\begin{array}{c}\text { Jumlah CFT } \\
\text { positif }\end{array}$ \\
\hline Kota Sorong & Sorong & 1 & 4 & 1 \\
\hline \multirow[t]{6}{*}{ Manokwari } & $\begin{array}{l}\text { Manokwari } \\
\text { Barat }\end{array}$ & 2 & 60 & 0 \\
\hline & $\begin{array}{l}\text { Manokwari } \\
\text { Utara }\end{array}$ & 3 & 19 & 0 \\
\hline & Masni & 6 & 157 & 4 \\
\hline & Prafi & 3 & 61 & 0 \\
\hline & Warmare & 4 & 47 & 0 \\
\hline & Sidey & 1 & 36 & 0 \\
\hline \multirow[t]{5}{*}{ Kab, Sorong } & Klamono & 1 & 25 & 0 \\
\hline & Malabotom & 1 & 15 & 0 \\
\hline & Mariat & 5 & 90 & 0 \\
\hline & Mayamuk & 1 & 4 & 0 \\
\hline & Salawati & 3 & 123 & 0 \\
\hline \multirow[t]{2}{*}{ Teluk Bintuni } & Bintuni & 1 & 24 & 0 \\
\hline & Jumla & 33 & 684 & 5 \\
\hline
\end{tabular}

Tindakan test and slaughter, melakukan surveilans, menguji dan memotong segera sapi reaktor brucellosis dapat mencegah penularan dan penyebaran penyakit. Hasil selengkapnya pengujian tertera pada Tabel 1 di atas.

Sebanyak 4 ekor sapi reaktor brucellosis ditemukan di desa Kalimerah, Kecamatan Masni di Manokwari, sedangkan 1 ekor lagi terdapat di desa Remu Utara, kecamatan Sorong di kota Sorong. Pemotongan dan surveilans berkelanjutan dengan metode sensus, mengambil serum pada semua sapi di kedua desa lokasi reaktor brucellosis sangat baik dilakukan untuk menghentikan penyebaran dan rantai penularan.

Kebijakan test and slaughter merupakan cara pengendalian brucellosis yang diambil oleh negara-negara di Asia Tenggara yang memiliki seroprevalensi brucellosis yang bervariasi. Seropravlensi brucellosis pada sapi potong tahun 2014 di Thailand 1\% sedangkan di Indonesia tercatat 2\%, di Malaysia dan Myanmar antara 4-5\% (Zamri-Saad et al., 2016). Kebijakan test and slaughter telah mampu menurunkan angka seroprevalensi brucellosis di Malaysia dari 5\% pada tahun 1979 menjadi 0,23\% pada tahun 1988 (ZamriSaad et al., 2016).

Seroprevalensi brucellosis pada sapi potong berbeda tiap negara dan jenis sapi. Untuk di Sudan, seroprevalensi brucellosis pada sapi potong sebesar 2,6\% (Mustafa, 2006). Makita et al. (2011) menemukan seroprevalensi brucellosis di Uganda untuk di tingkat 
Prosiding Seminar Nasional Pembangunan dan Pendidikan Vokasi Pertanian

Politeknik Pembangunan Pertanian Manokwari, 31 Juli 2021

e ISSN : 2774-1982

DOI : https://doi.org/10.47687/snppvp.v2i1.171

peternak sebesar 6,5\% sedangkan pada tingkat individu peternak sebesar 5,0\%. Seroprevalensi pada sapi potong betina dewasa secara nyata lebih besar ditemukan dibandingkan pada sapi dara di Ruanda (Ndarigaruye et al., 2018). Pada sapi jenis lain, sapi perah, Wilujeng et al. (2020), menemukan seroprevalensi sebesar 2\% di Banyuwangi. Brucellosis menimbulkan infeksi yang persisten, bakteri menetap pada sistem retikuloendotelial hewan terinfeksi (Poester et al., 2013). Replikasi bakteri pada infeksi terjadi pada kelenjar susu dan menetap pada limfoglandula supramamae (Meadorb et al., 1989). Surveilans, monitoring dan tindakan, sangat penting diterapkan untuk menurunkan seroprelensi yang tinggi (Khurana et al., 2020).

Aborsi akibat infeksi Brucella abortus timbul sebagai akibat bakteri yang banyak berkembang di plasenta sapi bunting, kelemahan dan kematian anak abortusan atau yang dilahirkan adalah sebagai akibat terjadinya pleuritis yang akut dan fibrinous (Poester et al., 2013).

\section{KESIMPULAN DAN SARAN}

Brucellosis sebagai penyakit menular yang zoonosis, ditemukan pada sapi potong di Papua Barat dengan seroprevalensi yang relatif rendah yaitu $0.73 \%$. Jumlah sapi rekator brucellosis yang ditemukan berdasar surveilans dan hasil uji serologis RBT dan CFT adalah 5 ekor dari 684 ekor sapi yang diuji serumnya. Sebanyak 4 ekor sapi reaktor brucellosis ditemukan di Kabupaten Manokwari dan 1 ekor di Kota Sorong.

Untuk mencegah penularan dan penyebaran penyakit, sapi-sapi yang reaktor brucellosis segera dipotong bersyarat dengan pengawasan petugas. Surveilans segera dilakukan di tingkat desa secara sensus dengan mengambil sampel serum sapi beresiko dan menguji secara serologis, dan segera memotong sapi reaktor brucellosis. Inseminasi buatan hendaknya dipergunakan intensif pada desa tertular brucellosis untuk menekan penyebaran penyakit akibat kawin alam.

\section{DAFTAR PUSTAKA}

Geresu, M.A. \& Kassa, G.M. (2016). A Review on diagnostic methods of brucellosis. J. of Vet. Sci. Tech., 2016 (7)3.

Getachew, T., Getachew, G., Sintayehu, G., Getenet, M., \& Fasil, A. (2016). Bayesian estimation of sensitivity and spesitifity of Rose Bengal Test and Direct ELISA Test for the diagnosis of brucellosis in Ethiophia. Vet Med Int., 8032753: 2016.

Khurana, S.K., Sehrawat, A., Tiwari, R., Prasad, M., Gulati, B., Shalbir, M.Z., Chabra, R., Karthik, K., Patel, S.K., Pathak, M., Yatoo, M.I., Gupta, V.K., Dharma, K., Sah, 
Prosiding Seminar Nasional Pembangunan dan Pendidikan Vokasi Pertanian

Politeknik Pembangunan Pertanian Manokwari, 31 Juli 2021

e ISSN : 2774-1982

DOI : https://doi.org/10.47687/snppvp.v2i1.171

R., \& Chaicumpa, W. (2021). Bovine brucellosis- a comprehensive review. Vet Quarterly., 41: 61-88.

Meadorb, V.P., Deyoea, L., \& Cheville, N.D.N.F. (1989). Pathogenesis of Brucella abortus infection of the mammary gland and supramammary lymph node of the goat. Vet Pathology, 26357: 368.

Mustafa, Y.M.S. (2010). Prevalence of Brucellosis in Cattle, Sheep and Goats of West Dafur State, Sudan. A Disertation Submitted to the University of Khartoum in Partial Fullfilment of the Degree of Master of Veterinary Science (Microbiology). Departement of Microbiology of Veterinry Medicine

Nasrullah, Nudirman, M., Ramadany, A., Ermansyah, L., Munawar, J.A., Nurzamin, A., Nurrohman, R.A., Priyono, Zaironi, A., \& Kurniawan, V.A. (2019). Statistika Peternakan dan Kesehatan Hewan, Livestock and Health Statistics. Direktorat Jenderal Peternakan dan Kesehatan Hewan, Kementerian Pertanian. Jakarta.

Neta, A.V.C., Mol, J.P.S., Xavier, M.N., Paixao, T.A., Lage, A.P., \& Santos, R.L. (2010). Pathogenesis of bovine brucellosis. Vet.J. 184(2): 146-155.

Poester, F.D. \& Samartino, L. (2013). Pathogenesis and pathobiology of brucellosis in livestock. Reviu Scientific et technique (International Office of Epizootics), 32 (1): 105-115.

Wilujeng, E., Suwarno, W., \& Praja, R.N. (2020). Serodeteksi brucellosis dengan metode Rose Bengal Test dan Complement Test dan Complemnet Fixation Test pada sapi perah di Banyuwangi. J. Med. Vet., 3 (2): 188.

Zamri-Saad, M. \& Kamarudin, M.I. (2016). Control of animal brucellosis: The Malaysian experience. J. APJTM, 9 (12): 1136-140.

Zakaria, A. (2018). Standard of the diagnosis of bovine brucellosis. Biomed and Pharmacology Journal, 1 (2): 951-957. 